\title{
Potential Drug Interactions with Coumadin (Warfarin) and Prozac (Fluoxetine): A Brief Report and Review of the Literature
}

\author{
Robert Jay Claire, M.D. \\ University of California, Martinez, California \\ Mark E. Servis, M.D. \\ University of California, Martinez, California \\ David L. Cram, Jr., Pharm.D. \\ University of California, Martinez, California
}

Follow this and additional works at: https://jdc.jefferson.edu/jeffjpsychiatry

Part of the Psychiatry Commons

Let us know how access to this document benefits you

\section{Recommended Citation}

Claire, M.D., Robert Jay; Servis, M.D., Mark E.; and Cram, Jr., Pharm.D., David L. (1991) "Potential Drug Interactions with Coumadin (Warfarin) and Prozac (Fluoxetine): A Brief Report and Review of the Literature," Jefferson Journal of Psychiatry. Vol. 9 : Iss. 2 , Article 10.

DOI: https://doi.org/10.29046/JJP.009.2.006

Available at: https://jdc.jefferson.edu/jeffjpsychiatry/vol9/iss2/10

This Article is brought to you for free and open access by the Jefferson Digital Commons. The Jefferson Digital Commons is a service of Thomas Jefferson University's Center for Teaching and Learning (CTL). The Commons is a showcase for Jefferson books and journals, peer-reviewed scholarly publications, unique historical collections from the University archives, and teaching tools. The Jefferson Digital Commons allows researchers and interested readers anywhere in the world to learn about and keep up to date with Jefferson scholarship. This article has been accepted for inclusion in Jefferson Journal of Psychiatry by an authorized administrator of the Jefferson Digital Commons. For more information, please contact: JeffersonDigitalCommons@jefferson.edu. 


\title{
Potential Drug Interaction with Coumadin (Warfarin) and Prozac (Fluoxetine): A Brief Report and Review of the Literature
}

\author{
Robert Jay Claire, M.D. \\ Mark E. Servis, M.D. \\ David L. Cram, Jr., Pharm. D.
}

\begin{abstract}
We were asked to see a woman with recurrent depression and a history of deep vein thrombosis. (Consultation and Liaison Service). She had been started initially on Prozac (fluoxetine) and was secondarily started on Coumadin (warfarin). The patient presented with severe bruising of both lower extremities. We were asked to investigate the case to determine if a drug interaction with Prozac had produced the problem. A review of the world's literature failed to produce a report of a drug interaction between Prozac and Coumadin producing a bleeding disorder. Scrutiny of this case could not produce evidence that this occurred. A retrospective analysis of 4 additional cases was performed. None of these patients required adjustment of their Coumadin while on Prozac.
\end{abstract}

It would be reasonable to assume that as the mean age of the United States population rises, the incidence of comorbid medical and psychiatric disease is increasing. Patients are often prescribed medications which may interact with psychotropic drugs. Second-generation antidepressants are generally considered safe drugs in the medically ill population because of their minimal anticholinergic properties and fewer adverse side effects. For the physician, a knowledge of drug interactions with the most commonly prescribed psychotropic medications is not only helpful, but should be the standard of care.

Recently, we were asked to see a woman with recurrent depression and a history of deep vein thrombosis. She had been initially started on Prozac (fluoxetine) and was secondarily started on Coumadin (warfarin). The patient presented with severe bruising of both lower extremities and a secondary cellulitis. An added complicating fact was that she had a Diptheria, Pertussis, Tetanus vaccination 3 weeks prior to admission. Both cellulitis and the D.P.T. vaccination potentially interfere with coagulation. On admission her Prothrombin Time (PT) was 50 and Partial Thromboplastin Time (PTT) was 100, a scenario more consistent with a coagulopathy rather than Coumadin toxicity.

When asked to consult on this case, we had to investigate the possibility of Prozac interacting with Coumadin. The Physicians Desk Reference cautions against coadministering the two drugs. (1) 
Coumadin, a commonly prescribed anticoagulant, is bound to the same plasma protein which binds Prozac. It is possible that Prozac may displace Coumadin from its binding protein and result in an increase in a free fraction of Coumadin, causing an increase in Protime $(1,3$,$) . A search of the medical literature fails to demonstrate any$ cases of Prozac interacting with Coumadin (2). In our case, a definite cause and effect linkage could not be established.

It was then elected to perform a retrospective chart review of patients who were coadministered Prozac and Coumadin. To date, we have reviewed an additional 4 cases.

Patient A is a 75 year old white male with a history of chronic obstructive pulmonary disease, coronary artery disease, multiple myocardial infarcts, atrial fibrillation, and recurrent transient ischemic attacks. The patient was found to have major depression and mild dementia. He had been on long term Coumadin therapy prior to the initiation of Prozac. At this juncture, Prozac and Coumadin have jointly been administered for 1 year. The patient maintained his PT ratio between 1.3 and 1.5 of PT control range without need to adjust the dosage.

Patient B, a 67 year old male, has a history of multiple cerebral vascular accidents. He presented to Mental Hygiene Clinic with major depression. To date, he has been maintained on Prozac and Coumadin for eight weeks. His PT has remained within satisfactory control limits without having to be adjusted.

Patient $\mathrm{C}$, a 73 year old male, is status post coronary artery bypass graft, and 11 peripheral vascular by-pass grafts. He has a history of deep vein thrombophlebitis and has been maintained on Coumadin therapy for 12 years. He was started on Prozac for depression 2 years ago. To date he has required no special adjustment to stay within control range.

Patient D is a 67 year old male with a history of deep vein thrombophlebitis, pulmonary emboli and squamous cell carcinoma of the tongue. He has undergone radical neck dissection and external beam radiation therapy. The patient has been on Coumadin for 12 years. His psychiatric history is remarkable for schizophrenia and intermittent depression. He was placed on Prozac 3 months ago, when he experienced orthostatic blood pressure changes from his tricyclic antidepressants. In the intervening period, he has required no special dosage adjustment to stay within parameters.

Our purpose in writing this report is to inform other clinicians that although in theory Coumadin and Prozac may interact and alter Prothrombin Time, the potential at this time appears small. Both Coumadin and Prozac can easily be displaced by other highly protein bound drugs. Prozac does not appear to alter the outcome of anticoagulant therapy significantly in the patients presented.

No cases of Coumadin interacting with Prozac have appeared in the world's literature (2). Our investigation involves 5 patients and cannot be considered definitive. It would be prudent to study a larger population before the safety of its combination with Coumadin can be determined.

Eli Lilly and Company, the manufacturers of Prozac, report that as of June 30, 
1990, approximately 2,382,000 patients have been on Prozac. There have been only 24 reported cases of increase in bleeding time, coagulation disorder, or coagulation time increase. We do not know whether any of these patients were concurrently on Prozac and Coumadin. It is our hope that this article challenges other investigators.

\section{REFERENCES}

1. Physicians Desk Reference 44th Edition, 1990, pages 905-908

2. Aidsline/Medline/Spiline Updated

3. Creasey WA: Effect of drug interactions in Drug Disposition in Humans. The Basis of Clinical Pharmacology, New York, Oxford University Press, 1979, Chap. 6. pp. 121-128

4. Hansten, PD: Drug Interactions, ed. 2. Philadelphia. Lea and Febiger, 1973, pp 2-12

5. Eli Lilly and Co., Spontaneous Reports of Adverse Events (post marketing through June 30, 1990). Unpublished data, supplied by company. 